\title{
Mortality and avoidance of competitive overgrowth in encrusting Bryozoa
}

\author{
John A. Rubin* \\ Department of Biological Sciences, Plymouth Polytechnic, Drake Circus, Plymouth PL4 8AA, United Kingdom
}

\begin{abstract}
Forty-five species of sessile animals, including 32 species of cyclostome and cheilostome bryozoans, settled on experimental panels over a 1 yr period. Colonies were readily overgrown by tubes of the serpulid Pomatoceros triqueter (L.) which became the dominant species on the panel community. However, a number of bryozoan species avoided competitive exclusion by settling preferentially or by growing epizoically onto the tubes which were, therefore, acting as spatial refuges from overgrowth by the serpulid. Since bryozoans are inferior interference spatial competitors but are known to have greater longevity than $P$. triqueter, vegetative growth of the surviving colonies and subsequent pre-emptive exploitative competition are probably the main processes which give rise to the replacement of the serpulid to produce the bryozoan-dominated communities on nearby boulders.
\end{abstract}

\section{INTRODUCTION}

Bryozoa are one of the predominant taxa in a variety of sublittoral epibenthic environments, including the undersides of foliaceous corals (e.g. Jackson 1979, Palumbi \& Jackson 1982, Winston \& Jackson 1984), rock faces (Castric 1974, Keough \& Downes 1982), shells (Harmelin 1977, Kay \& Keough 1981), boulders (Osman 1977, Rubin 1982) and artificial pilings (Lichtschein de Bastida \& Bastida 1980, Kay \& Keough 1981). Their predominance, together with other colonial taxa, over solitary groups is believed to be due to their ability to grow vegetatively: this, in turn, enables them to be superior overgrowth interference competitors since, in their expansion, they occlude the feeding and respiratory orifices of solitary species (Jackson 1977a, Keough 1984). They may also be superior pre-emptive exploitative competitors (sensu Schoener 1983) since, having occupied space on the primary substratum, they are able to prevent its occupation by other species through growth (Karlson 1978, Sebens in press) or larval recruitment (e.g. Standing 1976, Sutherland 1978, Day \& Osman 1982).

The community on the underside of boulders in the shallow sublittoral off southwest England is dominated by bryozoans, particularly cheilostomes (Rubin 1982),

- Present address: 20 Leyford Close, Wembury, Plymouth PL9 OHX, United Kingdom whereas artificial panels which were submerged in a similar environment off northwest France for up to $3 \mathrm{yr}$ were dominated by the solitary serpulid Pomatoceros triqueter (Castric 1974). This species rarely occupies $>5 \%$ of the space on the undersides of the boulders.

In this paper I describe the outcome of spatial encounters between Pomatoceros triqueter and bryozoans on artificial panels submerged in the vicinity of the boulders. I also report on growth and larval settlement strategies employed by some bryozoan species to avoid overgrowth mortality of very young colonies and discuss these in the context of the roles of interference and exploitative competition in structuring the boulder community.

\section{MATERIALS, METHODS AND STUDY SITE}

Forty-eight $150 \times 150 \times 4 \mathrm{~mm}$ black perspex panels were submerged on 10 Feb 1981. The panel frame consisted of a cast-iron single bed with the springs removed. The panels were bolted onto metal straps which were themselves bolted onto the frame. This remained in a horizontal position.

Four panels, selected by using random number tables, were collected using SCUBA on 9 separate occasions over a 1 yr period. These panels were placed in $5 \%$ neutralised seawater formaldehyde until they could be examined under the stereo-microscope for 
identification and counting of individuals; each colony was scored as 1 individual. Percent cover was determined by superimposing an acetate sheet with $15 \times 15$ $=225$ equidistant points marked onto it, such that a margin $12 \mathrm{~mm}$ wide was not sampled around the periphery of each panel, thereby avoiding possible edge effects

R-type cluster analysis was carried out on the frequency data matrix, in order to group species quantitatively with a similar pattern of occurrence over the duration of the experiment. This was carried out using the CLUSTAN program (Wishart 1978). The technique followed was that of Field et al. (1982): raw data were root-root transformed and standardised, and the similarity index used was the Bray-Curtis coefficient (Bray \& Curtis 1957). However, unlike Field et al., Principal Components Analysis was used in the ordination, the number of species was not reduced and the singlelinkage clustering method was followed.

The site chosen for submergence of the panel frame was $50 \mathrm{~m}$ to the south of Plymouth Breakwater, outside Plymouth Sound in southwest England (map ref $50^{\circ}$ $21^{\prime} \mathrm{N}, 04^{\circ} 08^{\prime} \mathrm{W}$ ) at a depth of $8 \mathrm{~m}$. The frame was placed $<1 \mathrm{~m}$ away from the base of the limestone blocks of which the Breakwater is composed. It rested on a substratum of sand and $10 \mathrm{~m}$ away from an accumulation of boulders which were up to $50 \mathrm{~cm}$ long. These acted as a probable source for colonization of panels, since the larval period of many bryozoans is short (Hayward \& Ryland 1979).

\section{RESULTS}

During the early months of submergence of the panels, colonization occurred by a number of species belonging to both solitary and colonial taxa, including spirorbids, a few Pomatoceros triqueter and cyclostome and cheilostome bryozoans. In July 1981 there was a massive spatfall of $P$. triqueter; subsequently these overgrew all other species which they encountered on the primary substratum through distal and lateral expansion of their tubes. The species overgrown consisted predominantly of cyclostome bryozoans (Fig. 1 \& 2), spirorbids and Anomia ephippium L. Overgrowth mortality of $P$. triqueter through occlusion of the orifice by bryozoans was never observed. Tubulipora liliacea (Pallas) suffered particularly high mortality as a result of overgrowth by $P$. triqueter (Fig. 2). Crowding by the serpulid also had an effect on some of the colonies which survived: these exhibited elongate and separate zooecia extending away from the panel surface (Fig. 3). Some cheilostome colonies which had already established were able to escape overgrowth mortality by growing epizoically onto tubes of neighbouring $P$. triqueter (Fig. 4).

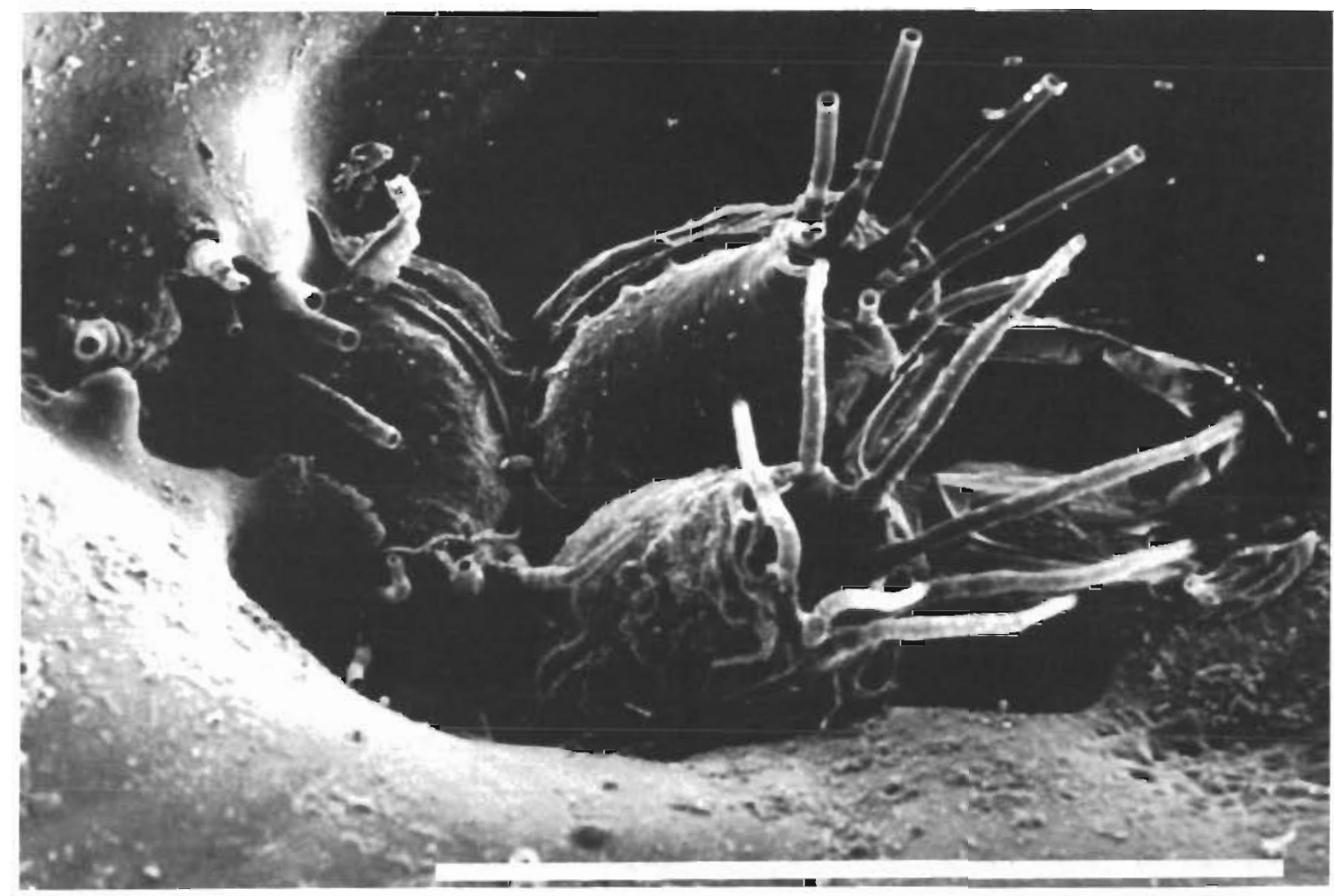

Fig. 1. Escharoides coccinea. Colony partly overgrown by Pomatoceros triqueter. Scale bar $=100 \mu \mathrm{m}$ 
Fig. 2. Tubulipora liliacea. Zooecia emerging from the side of a Pomatoceros triqueter tube. Rest of colony has been overgrown. Scale bar $=100 \mu \mathrm{m}$

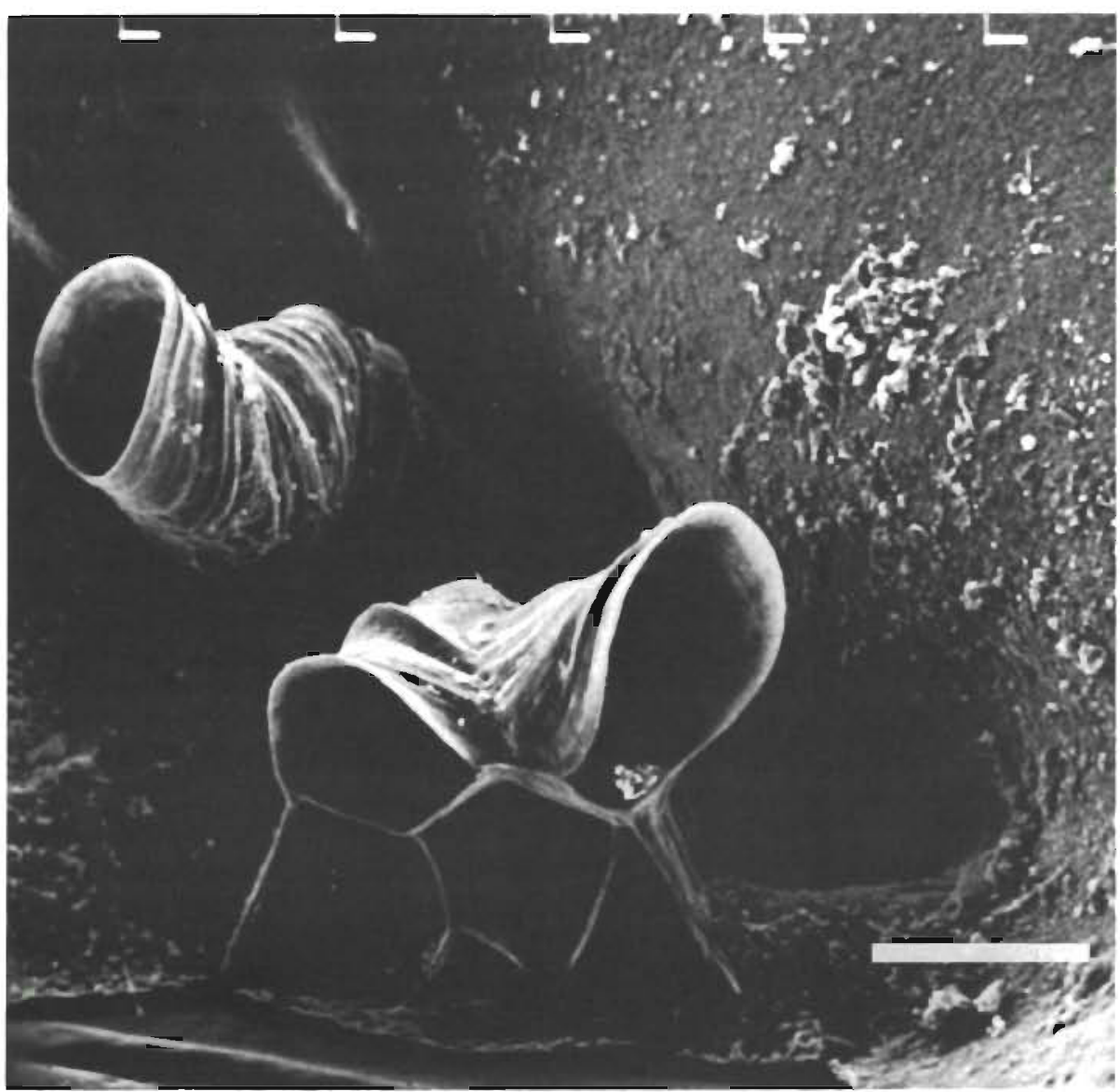

Some cheilostomes were also able to avoid competitive overgrowth by settling predominantly or exclusively on the tubes, although away from the apex (Fig. $5 \& 6$ ). Table 1 gives the results of a $\chi^{2}$ goodnessof-fit which tests the null hypothesis that there was no difference between the observed and expected frequencies of very young colonies consisting of 1 or 2 zooids (ancestrula and first peri-ancestrula) occuring on the Pomatoceros triqueter tubes, i.e. that these young colonies were derived from larvae which had settled randomly on the panels. This null hypothesis was tested for each of the 9 most abundant cheilostome species on the 8 panels collected on 15 Sept 1981 and 31 Oct 1981 . These 2 dates were chosen since they covered a period during which many cheilostome larvae were settling and the percentage cover of $P$. triqueter was fairly high (mean $=32.56$ ). Since cheilostome larvae also colonized both solitary species (other than $P$. triqueter) and Electra pilosa (L.), the latter were regarded as substrata which, together with bare panel

Table 1. Number of colonies consisting of 1 or 2 zooids for the 9 commonest cheilostome species on panels collected on 15 Sep 1981 and 31 Oct 1981

\begin{tabular}{|lccrrrr|}
\hline \multicolumn{1}{c}{ Species } & $\begin{array}{c}\text { Total no. } \\
\text { colonies }\end{array}$ & $\begin{array}{c}\text { No. colonies on } \\
\text { P.triqueter tubes }\end{array}$ & $\%$ & $\chi^{2}$ & P \\
\hline Callopora rylandi & 26 & 26 & 100 & 46.22 & $<0.001$ & 1 \\
Cauloramphus spiniferum & 124 & 118 & 95.16 & 188.37 & $<0.001$ & 3 \\
Celleporella hyalina & 94 & 25 & 26.60 & 3.61 & $>0.05$ & 5 \\
Celleporina hassallii & 39 & 31 & 79.49 & 32.01 & $<0.001$ & 2 \\
Chorizopora brongniartii & 14 & 14 & 100 & 24.89 & $<0.001$ & 4 \\
Escharoides coccinea & 45 & 45 & 100 & 80.00 & $<0.001$ & 4 \\
Membraniporella nitida & 31 & 24 & 77.42 & 23.08 & $<0.001$ & 3 \\
Microporella ciliata & 72 & 32 & 44.44 & 2.23 & $>0.05$ & 5 \\
Schizomavella linearis & 104 & 79 & 75.96 & 72.08 & $<0.001$ & 2 \\
\hline
\end{tabular}




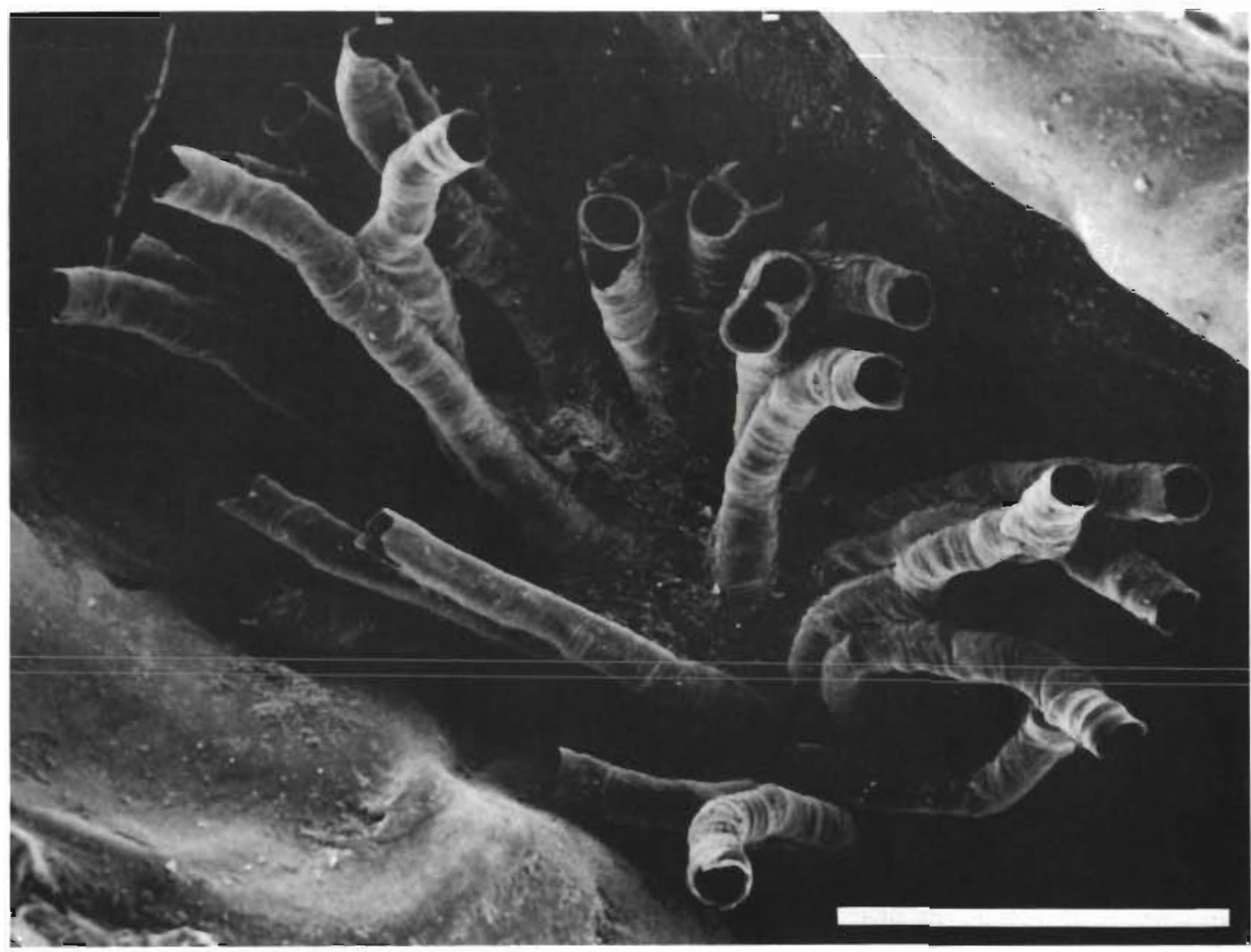

Fig. 3. Tubulipora liliacea. Colony, spatially restricted between 2 Pomatoceros triqueter tubes, has produced elongate zooecia. Scale bar $=1 \mathrm{~mm}$

surface, were available for colonization. The mean percentage cover of these areas collectively was 58.62. The only areas which were not regarded as available for colonization by cheilostome larvae were other colonial species (mean percentage cover $=8.22$ ). These were mostly established cheilostomes. The expected frequencies for each species (the number of these very young colonies which would have occurred on the $P$. triqueter tubes if larval settlement had been random) were derived from the mean percentage cover values for the serpulid given above, with a correction to take account of the presence of these other colonial species.

Table 1 shows that this null hypothesis should be rejected for 7 of the 9 species, viz. their ancestrulae occurred preferentially on the sides of Pomatoceros triqueter tubes (all $\mathrm{P}<0.001$ ). In 3 of them-Callopora rylandi Bobin \& Prenant, Chorizopora brongniartii (Audouin) and Escharoides coccinea (Abildgaard) - all of the ancestrulae occurred on the tubes. If one also considers that 3 of the 9 species - C. rylandi, Cauloramphus spiniferum (Johnston) and Membraniporella nitida (Johnston) - were never recorded on younger poorly colonized panels also present on the frame at this time (Rubin unpubl.), it is possible to discern 5 patterns of settlement selection: (1) larvae settled exclusively on $P$. triqueter tubes and never on other available areas of mature panels nor on poorly colonized panels present at the time (C. rylandi); (2) larvae settled on $P$. triqueter tubes but also settled elsewhere on other available areas of mature panels and on poorly colonized panels present at the time (Celleporina hassallii [Johnston], Schizomavella linearis [Hassall]); (3) as (2) but no settlement on poorly colonized panels present at the time (C. spiniferum, $M$. nitida); (4) as (2) but no settlement on other available areas of mature panels (C. brongniartii, E. coccinea); (5) settlement pattern not significantly different (P > 0.05) from random (Celleporella hyalina [L.], Microporella hyalina [Pallas]). Settlement type (1) suggests a highly selective settlement behaviour pattern and type (5) little or no substratum selectivity.

The inverse (R-type) analysis of the data (Fig. 7) grouped together 35 species on the panels into a single, Iarge cluster, whereas the more abundant species were more scattered on the ordination plot. In particular, Pomatoceros triqueter plotted away from the rest of the species in the community, while Celleporella hyalina, Escharoides coccinea and Microporella ciliata plotted together in a cluster intermediate in position between $P$, triqueter and the large cluster. 
Fig, 4. Escharoides coccinea. Colony partly overgrown by a Pomatoceros triqueter tube but escaping overgrowth at its distal end by epizoic growth onto another tube. Scale bar

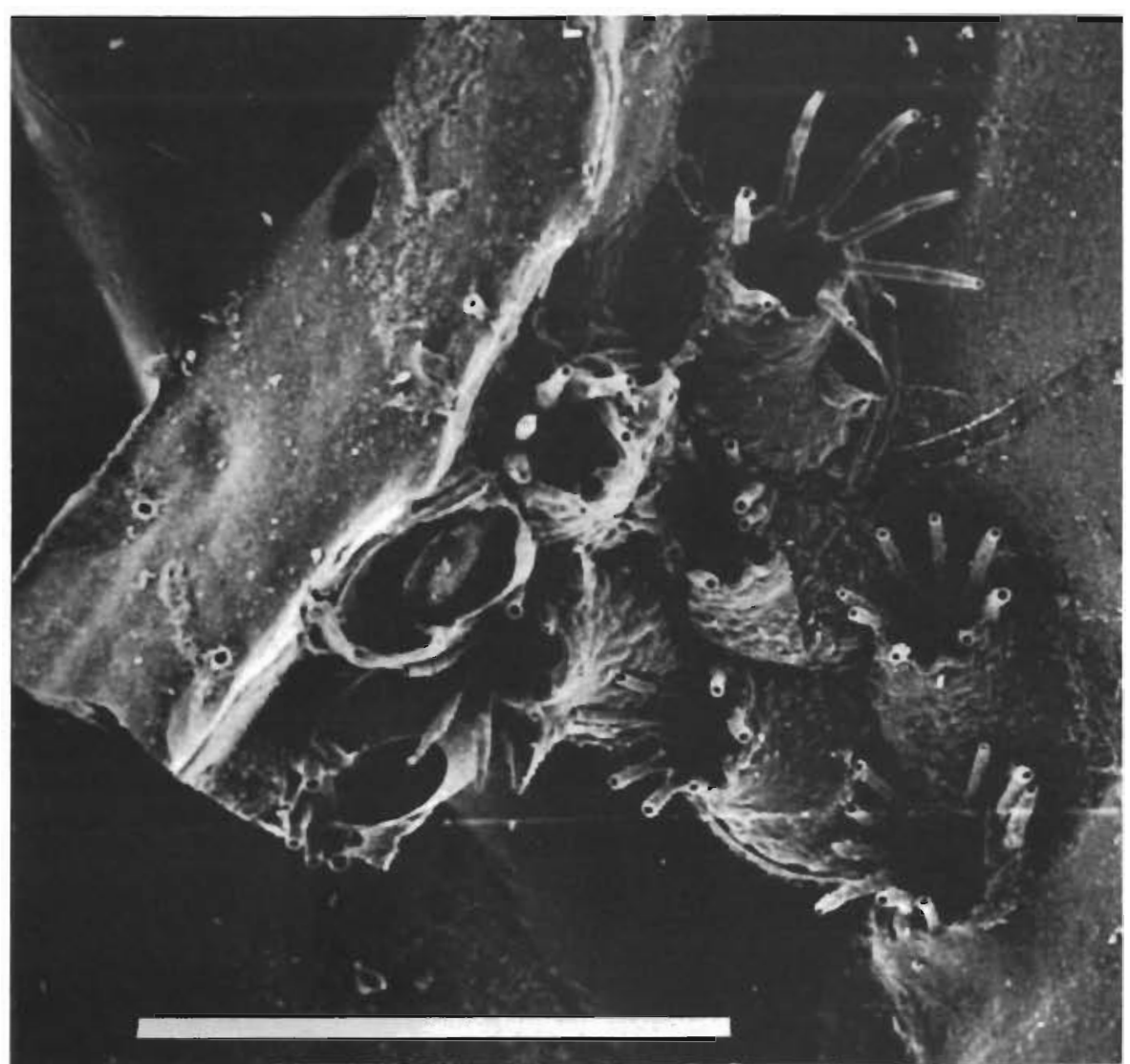

$$
=1 \mathrm{~mm}
$$

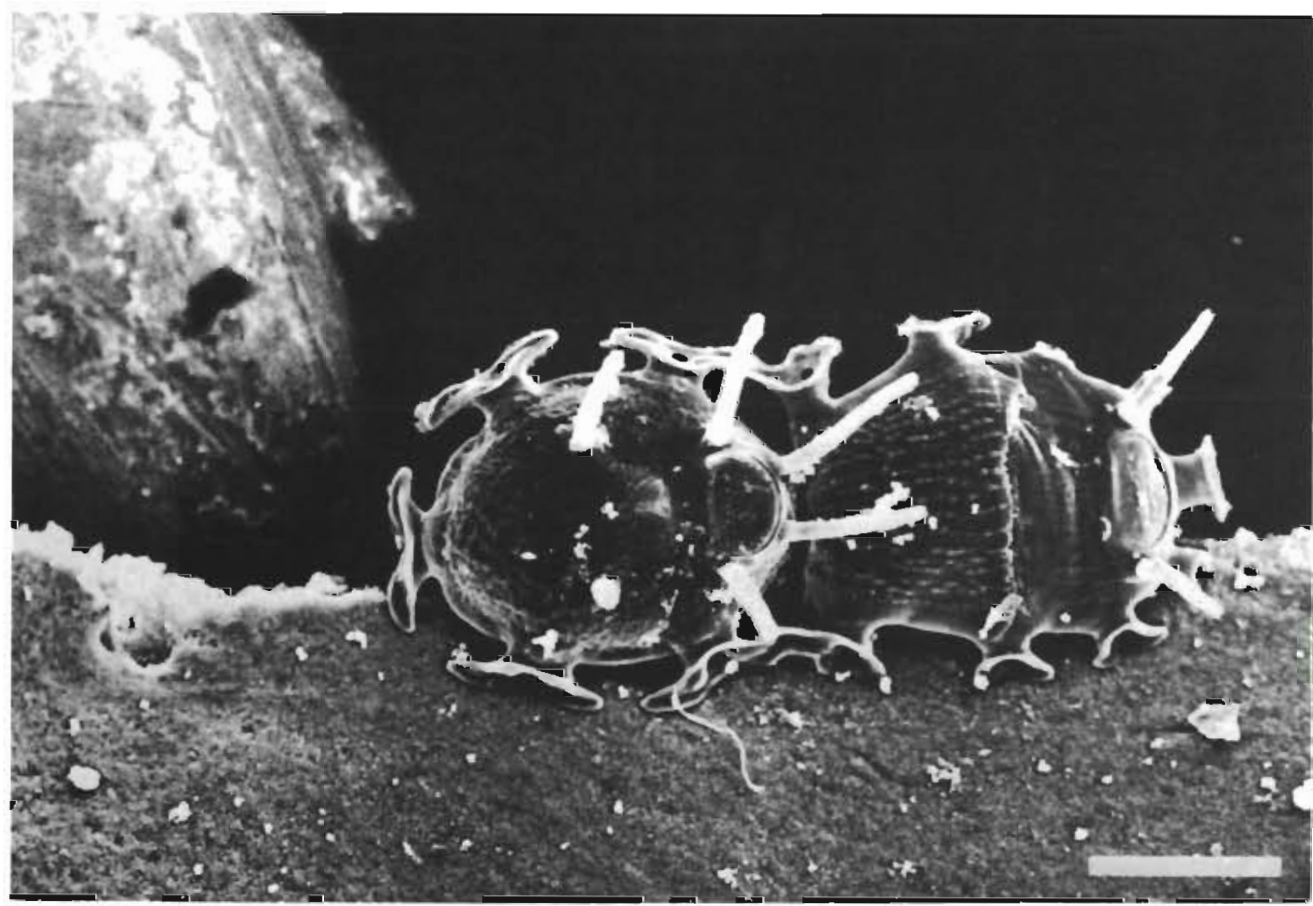

Fig. 5. Chorizopora brongniartii. Ancestrula and first peri-ancestrula on the side of a Pomatoceros triqueter tube. Scale bar $=$ $100 \mu \mathrm{m}$ 


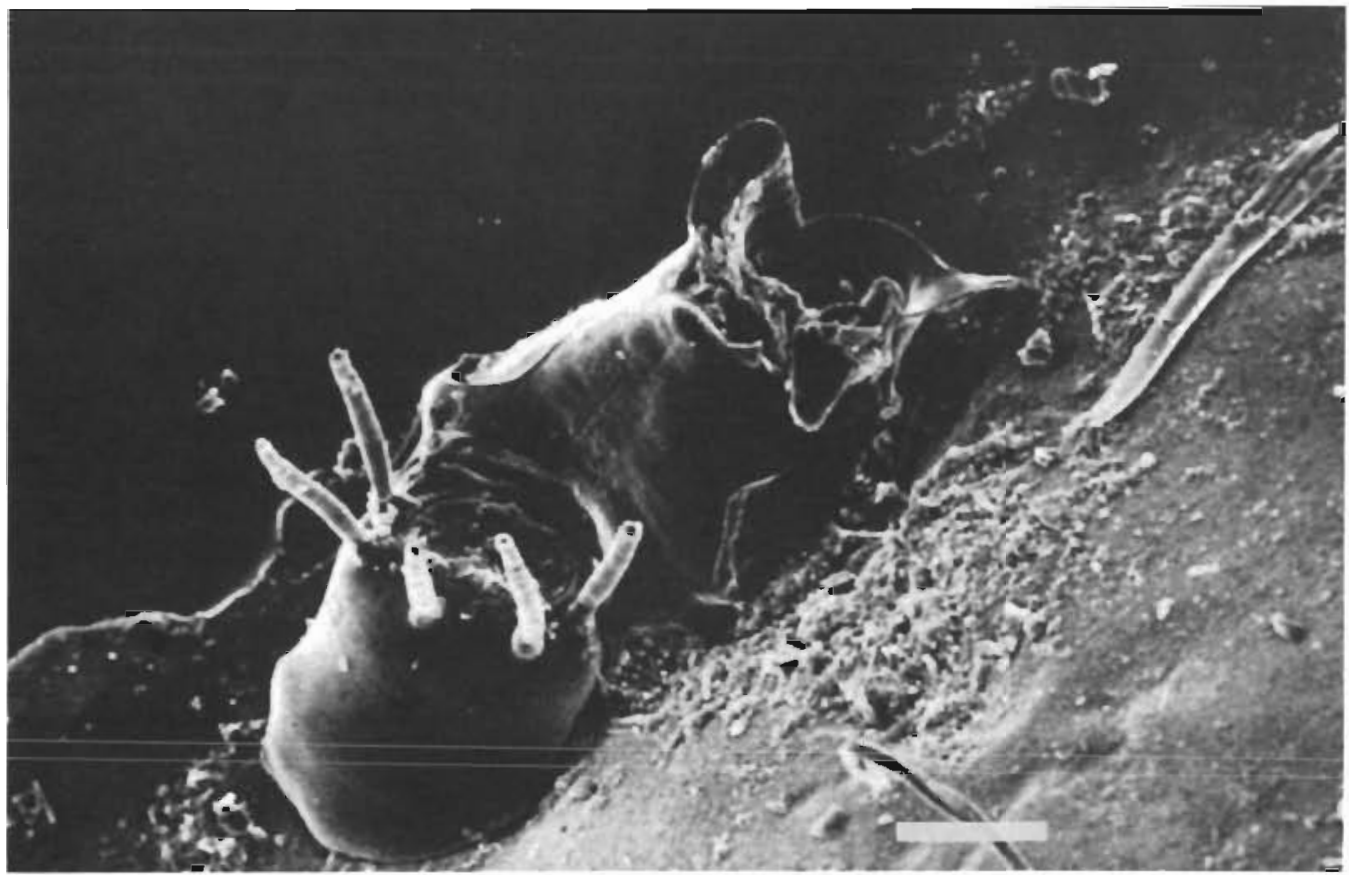

Fig. 6. Celleporina hassallii. Ancestrula and first peri-ancestrula on the side of a Pomatoceros triqueter tube. Scale bar $=100 \mu m$

Electra pilosa occurred as another outlier, reflecting its high abundance in the early stages of the experiment, in contrast to most of the other species.

\section{DISCUSSION}

\section{Role of different competitive mechanisms in structuring epibenthic communities}

Although a number of authors (e.g. Jackson 1977b, Scheltema et al. 1981, Schmidt 1983) have shown that aggregated, established solitary animals can inhibit

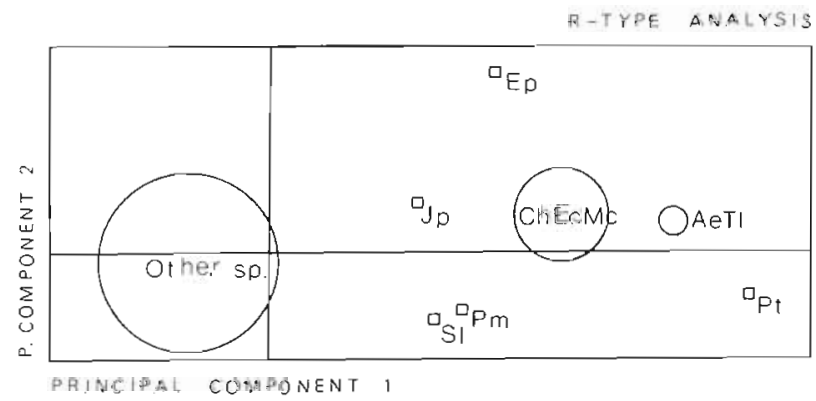

Fig. 7. Cluster diagram resulting from the R-type Principal Components Analysis of the frequency data matrix. Abbreviations: Ae Anomia ephippium, Ch Celleporella hyalina, Ec Escharoides coccinea, Ep Electra pilosa, Jp Janua pagenstecheri (Quatrefages), Mc Microporella ciliata, Pm Paralaeospira malardi Caullery \& Mesnil, Pt Pomatoceros triqueter, Sl Schizomavella linearis, TI Tubulipora liliacea settlement by the larvae of colonial species - while others (e.g. Stebbing 1973, Jackson 1977a) have demonstrated that solitary animals, such as serpulids, are able to avoid overgrowth mortality by colonial species through vertically elevating the orifice away from the substratum - the overgrowth of cheilostome bryozoans by Pomatoceros triqueter is obviously a different phenomenon altogether. In particular, it contradicts the suggestion that solitary groups are inferior overgrowth interference competitors to colonial ones and shows that not all serpulids are ineffective space competitors (cf. Jackson 1977 a), although small spirorbids may be (Keough 1984).

There are other examples in which solitary animals have been shown to be superior interference spatial competitors: Castric (1974) reported that Pomatoceros triqueter was capable of overgrowing thinly encrusting bryozoans, and E. Voigt (pers. comm.) showed that cheilostomes growing on hard substrata of Cretaceous age had been overgrown by serpulids while they were still alive. Furthermore, Haderlie (1974) demonstrated that bamacles were capable of displacing bryozoans by undercutting them, while Montanari \& Relini (1974) found that colonies of the ascidian Botryllus schlosseri fragmented when they came into contact with small, recently settled barnacles and serpulids.

If, as appears likely, the cheilostome-dominated community on the underside of nearby boulders is a later successional stage than the one on the panels, the problem arises of how a strong overgrowth spatial competitor can eventually be replaced by weaker ones. 
(Since there are occasional boulders which are almost entirely covered by Pomatoceros triqueter, it is unlikely that the difference between the 2 communities can be explained in terms of preferential larval settlement, with $P$. triqueter preferring panels and cheilostomes preferring boulders.) Although estimates of the longevity of $P$. triqueter in northern European waters vary from 18 mo (Føyn \& Gjøen 1954) to 30 mo (Castric 1983), many cheilostomes live longer than this (Eggleston 1972, Winston \& Jackson 1984), even though partial senescent mortality does occur in the latter (Jackson \& Winston 1981). In this paper 2. strategies for reducing the overgrowth mortality of cheilostomes by $P$. triqueter have been described, viz. epizoic growth onto neighbouring tubes (Fig. 4) and selective larval settlement onto the tubes (Table $1_{i}$ Fig. 5 \& 6). Therefore it is likely that, by avoiding competitive exclusion in the early stages of community development, by having greater longevity, and by subsequently inhibiting further settlement of $P$. triqueter, cheilostomes are eventually able to replace the serpulid in the development of the community. In other words, it is the pre-emptive exploitative competitive ability of this group of colonial animals and not superior interference competitive ability which enables them to dominate in certain epibenthic communities.

Greene \& Schoener (1982) and Greene et al. (1983) also recognised the importance of longevity and of subsequent pre-emptive exploitative competition in structuring epibenthic communities on artificial panels, although they found that various species of solitary animal eventually became dominant through having greater longevity. All of these apparently contradictory results serve to underline the importance of having a detailed knowledge of the life-history characteristics of the participating species before making predictions or generalizations concerning the role of spatial interactions in structuring epibenthic communities.

The clustering together of Celleporella hyalina, Escharoides coccinea and Microporella ciliata on the ordination plot (Fig. 7) suggests that spatial competition between these cheilostomes, the most abundant on the panels, was not a major factor in structuring the panel community (although some interspecific overgrowth between them did occur). This is despite the fact that they have very different overgrowth competitive abilities (Rubin 1982), with E. coccinea being a very strong competitor and $M$. ciliata a weak one. $C$. hyalina is a particularly weak overgrowth competitor (Rubin unpubl.) and exists predominantly as an epiphyte (Hayward \& Ryland 1979). The plotting of Pomatoceros triqueter as an outlier in Fig. 7 reflects its numerical dominance throughout most of the period of panel submergence, very largely as a result of its formidable overgrowth competitive ability.

\section{Recruitment and location of spatial refuges by cheilostome larvae}

I suggest that, by selective epizoic settlement onto Pomatoceros triqueter tubes, cheilostome larvae were locating spatial refuges from overgrowth mortality of the very youngest zooids. Although it is known that larger colonies are able to suffer partial mortality without loss of the entire genet (Jackson 1977a, Jackson \& Winston 1981, Palumbi \& Jackson 1982), a characteristic of modular organisms in general (see Harper 1981 for review), mortality of even a very few zooids in the initial stages of colony growth would have a much more serious effect: the need to maintain the viability of the ancestrula may be particularly important since, if it were killed off, perhaps by overgrowth, translocation of nutrients across the growing colony would be seriously affected. D'Hondt (1976) found that, by killing off the ancestrula in very young colonies of Alcyonidium polyoum, further colony growth was inhibited. Furthermore in a number of species, including Celleporina hassallii and Schizomavella linearis, frontal budding commences directly above the ancestrula (Fig. 8; Schaaf 1974); presumably, therefore, mortality of the ancestrula would also inhibit this type of growth. Undoubtedly the statement by Silén $(1977$, p. 213) that the ancestrula has no special function in the life of the developed colony except constituting the primary or sometimes the only holdfast' requires qualification and it would be interesting to ascertain the minimum size which a colony needs to reach, beyond which mortality of the ancestrula would no longer inhibit growth.

While it has been recognised that small, isolated substrata can act as refuges for competitively subordinate species (Harmelin 1977, Jackson 1977b, Kay \& Keough 1981, Keough 1983), together with environments inimical to the growth of competitive dominants (Harmelin 1980), refuges in the form of microhabitats which can be located by larvae and which would, in turn, confer increased fitness on the adults by avoiding overgrowth mortality have been recognised by a number of authors. Larval settlement patterns designed to locate such refuges include: (1) aggregative settlement by competitively subordinate bryozoans (Buss 1981); (2) selective settlement by bryozoans onto live adult colonies of their own species (Gordon 1970); (3) selective settlement by species close to competitive subordinates (Buss 1979, Keen \& Neill 1980); (4) selective settlement by a subordinate species away from competitive dominants (Grosberg 1981, Sebens 1983); (5) selective epizoic settlement onto 


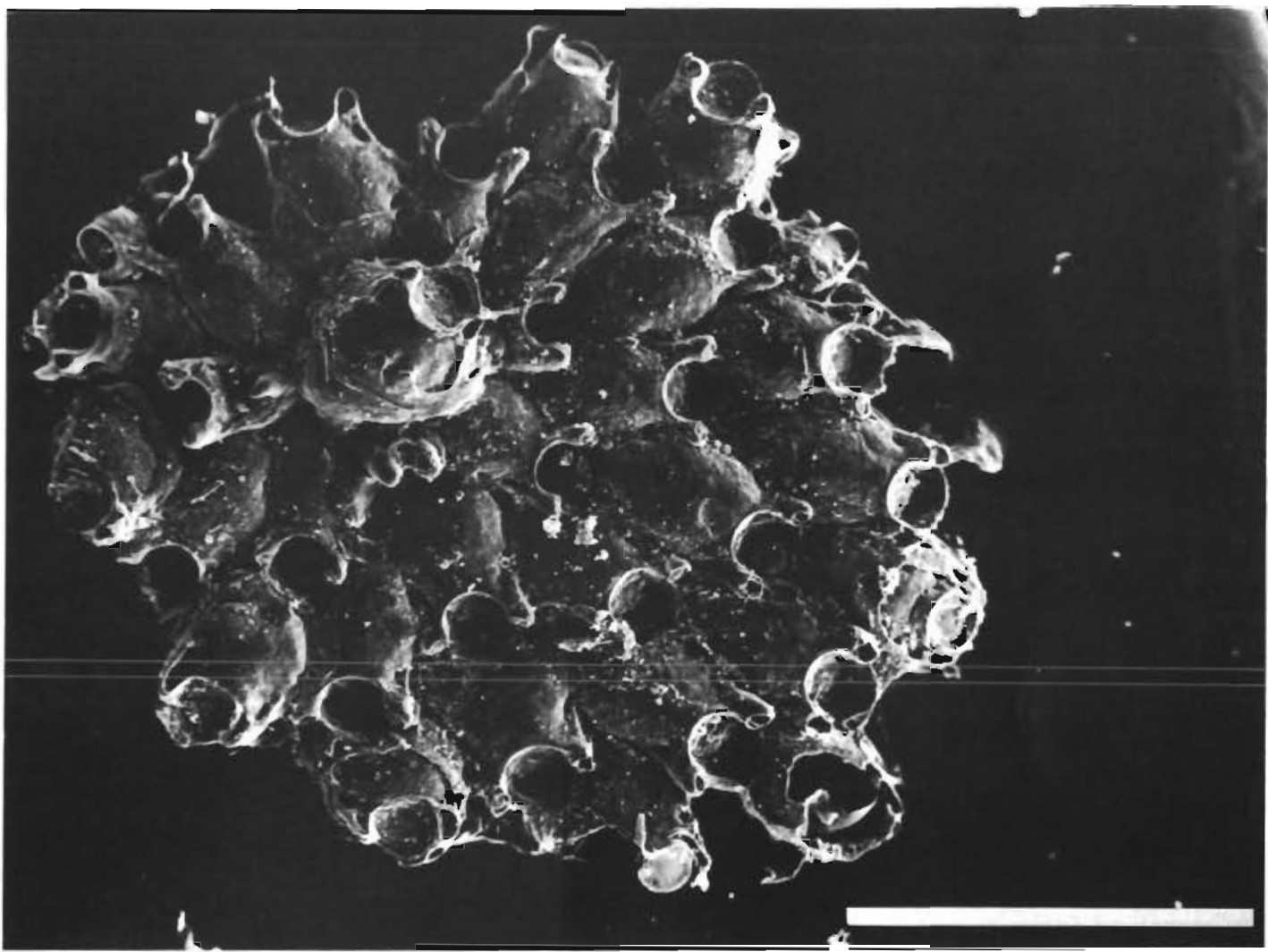

Fig. 8. Celleporina hassallii. Young colony with first frontally-budded zooid growing directly above the ancestrula. Scale bar $=$ $1 \mathrm{~mm}$

inert parts of a competitive dominant (this study). In addition, Young \& Chia (1981) have shown that larvae of competitively subordinate species can delay settlement when competitive dominants are present: this would increase the likehood of one of these types of refuge being located.

Acknowledgements. I thank Dr. A. R. D. Stebbing, Dr. G. F Warner and L. Scott, as well as 2 anonymous reviewers, for their comments on an earlier version of the manuscript. This work was undertaken in partial fulfilment of a Ph. D. degree of the University of Reading, U.K., supervised by Drs G. F. Warner and J. M. Hinton.

\section{LITERATURE CITED}

Bray, J. R., Curtis, J. T. (1957). An ordination of the upland forest communities of Southern Wisconsin. Ecol. Monogr. 27: $325-349$

Buss, L. W. (1979). Habitat selection, directional growth and spatial refuges: why colonial animals have more hiding places. In: Larwood, G., Rosen, B. R. (eds.) Biology and systematics of colonial organisms. Academic Press, New York, p. 459-497

Buss, L. W. (1981). Group living, competition and the evolution of cooperation in a sessile invertebrate. Science 213 1012-1014

Castric, A. (1974). Les peuplements sessiles du benthos rocheux de l'archipel de Glénan, Sud Bretagne: écologie descriptive et expérimentale. Unpubl. doctoral thesis, Université de Paris VI

Castric, A. (1983). Recrutement, croissance et longévité de Pomatoceros triqueter et de Pomatoceros lamarkii sur plaques expérimentales en Baie de Concarneau (Sud Finistère). Annls. Inst. océanogr. Paris 59: 69-91

Day, R. W., Osman, R. W. (1982). Predation by Patiria miniata (Asteroidea) on bryozoans: prey diversity may depend on the mechanism of succession. Oecologia (Berl.) 51: 300-309

Eggleston, D. (1972). Patterns of reproduction in the marine Ectoprocta of the Isle of Man. J. Nat. Hist. 6: 31-38

Field, J. G., Clarke, K. R., Warwick, R. M. (1982). A practical strategy for analysing multispecies distribution patterns. Mar. Ecol. Prog. Ser. 8: 37-52

Føyn, B., Gjøen, I. (1954). Studies on the serpulid Pomatoceros triqueter L.: observations on the life history. Nyt. Mag. Zool. 2: $73-81$

Gordon, D. (1970). Reproductive ecology of some Northern New Zealand Bryozoa. J. Nat. Hist. 6: 31-38

Greene, C. H., Schoener, A. (1982). Succession on marine hard substrata: a fixed Iottery. Oecologia (Berl.) 55: 289-297

Greene, C. H., Schoener, A., Corets, E. (1983). Succession on marine hard substrata: the adaptive value of solitary and colonial strategies in temperate fouling communities. Mar. Ecol. Prog. Ser 13: 121-129

Grosberg, R. K. (1981). Competitive ability influences habitat choice in marine invertebrates. Nature, Lond. 290: $700-702$ 
Haderlie, E. C. (1974). Growth rate, depth preference and ecological succession of some sessile marine invertebrates in Monterey Harbor. Veliger 17: 1-35

Harmelin, J.-G. (1977). Bryozoaires des îles d'Hyères: cryptofaune bryozoologique des valves vides de Pinna nobilis rencontrées dans les herbiers de Posidonies. Trav. Sci. Parc Natl. Port-Clos 3: 89-120

Harmelin, J.-G. (1980). Etablissement des communautés de substrats durs en milieu obscur. Résultats préliminaires d'une expérience à long terme en Méditerranée. Memorie Biol. mar. Oceanogr. 10: 29-52

Harper, J. L. (1981). The concept of population in modular organisms. In: May, R. M. (ed.) Theoretical ecology. Blackwell, Oxford p. 53-77

Hayward, P. J., Ryland, J. S. (1979). British ascophoran bryozoans: synopses of the British fauna, Linn. Soc. Academic Press, London

Hondt, J.-L. d' (1976). Effets sur l'ablation de l'ancestrula ou de la première zooécie-fille sur le développement d'une jeune colonie du Bryozoaire ctenostome Alcyonidium polyoum (Hassall). Bull. Soc. zool. Fr. 101: 993-995

Jackson, J. B. C. (1977a). Competition on marine hard substrata: the adaptive significance of solitary and colonial strategies. Am. Nat. 111: 743-767

Jackson, J. B. C. (1977b). Habitat area, colonization and the development of epibenthic community structure. In: Keegan, B. F., O'Ceidigh, P., Boaden, P. J. S. (eds.) The biology of benthic organisms. Proc. 10th Europ. mar. Biol. Symp. Pergamon, Oxford, p. 349-358

Jackson, J. B. C. (1979). Overgrowth competition between encrusting cheilostome ectoprocts in a Jamaican cryptic reef environment. J. Anim. Ecol. 48: 805-823

Jackson, J. B. C., Winston, J. E. (1981). Modular growth and longevity in bryozoans. In: Larwood, G. P., Nielsen, C. (ed.) Recent and fossil Bryozoa. Olsen and Olsen, Fredensborg, p. 121-126

Karlson, R. (1978). Predation and space utilization patterns in a marine epifaunal community, J. exp. mar. Biol. Ecol. 31 : 225-239

Kay, A. M., Keough, M. J. (1981). Occupation of patches in the epifaunal communities on pier pilings and the bivalve Pinna bicolor at Edithburgh, South Australia. Oecologia (Berl.) 48: 123-130

Keen, S. L., Neill, W. E. (1980). Spatial relationships and some structuring processes in benthic intertidal animal populations. J. exp. mar. Biol. Ecol. 45: 139-155

Keough, M. J. (1983). Patterns of recruitment of sessile invertebrates in two subtidal habitats. J. exp. mar. Biol. Ecol. 66: 213-245

Keough, M. J. (1984). Dynamics of the epifauna of the bivalve Pinna bicolor. interactions among recruitment, predation and competition. Ecology 65: 677-688.

Keough, M. J., Downes, B. J. (1982). Recruitment of marine invertebrates: the role of active larval choices and early mortality. Oecologia (Berl.) 54: 384-352

Lichtschein de Bastida, V., Bastida, R. (1980). Los briozoos incrustes de puertos argentinos. In: 5th Int. Congress on Marine Corrosion and Fouling, Garsi, Madrid, p. 371-390

Montanari, M., Relini, G. (1974). Osservazioni preliminari sull accrescimento di Botryllus schlosseri su substrati artificiali immersi in mare. Memorie Biol. mar. Oceanogr. 4: $373-403$

Osman, R. W. (1977). The establishment and development of a marine epifaunal community. Ecol. Monogr. 47: 37-63

Palumbi, S. R., Jackson, J. B. C. (1982). Ecology of cryptic coral reef communities II. Recovery from small disturbance events by encrusting Bryozoa: the influence of 'host' species and lesion size. J. exp. mar. Biol. Ecol. 64: 103-115

Rubin, J. A. (1982). The degree of intransitivity and its measurement in an assemblage of encrusting cheilostome $\mathrm{B}$ гуozoa. J. exp. mar. Biol. Ecol. 60: 119-128

Schaaf, A. (1974). Les modalités de la croissance et ses altérations chez quelques bryozoaires cheilostomes. Application à l'espèce Steginoporella rhodanica Buge et David, 1967. Trav. Lab. Géol. Univ. Lyon 60: 1-82

Scheltema, R. S., Williams, I. P., Shaw, M. A., Loudon, C. (1981). Gregarious settlement by the larvae of Hydroides dianthus (Polychaeta: Serpulidae). Mar. Ecol. Prog. Ser. 5: 69-74

Schmidt, G. H. (1983). Studies on the development of fouling communities on experimental panels in Langstone Harbour. Unpubl. Ph. D. thesis, University of Reading, U.K.

Schoener, T. W. (1983). Field experiments on interspecific competition. Am. Nat. 122: 240-284

Sebens, K. P. (1983). The larval and juvenile ecology of Aplidium siderum Verrill. I. Substratum selection by benthic larvae. J. exp. mar. Biol. Ecol. 71: 73-89

Sebens, K. P. (in press). Spatial relationships among encrusting marine organisms in the New England subtidal. Ecology

Silén, L. (1977). Polymorphism. In: Woollacott, R. M., Zimmer, R. L. (ed.) Biology of Bryozoa. Academic Press, New York, p. 183-232

Standing, J. D. (1976). Fouling community structure: effects of the hydroid Obelia dichotoma on larval recruitment. In: Mackie, G. O. (ed.) Coelenterate ecology and behaviour. Plenum Press, New York, p. 155-164

Stebbing, A. R. D. (1973). Competition for space between the epiphytes of Fucus serratus L. J. mar. biol. Ass. U.K. 53; $247-261$

Sutherland, J. P. (1983). Functional roles of Schizoporella and Styela in the fouling community at Beaufort, North Carolina. Ecology 59: 257-264

Winston, J. E., Jackson, J. B. C. (1984). Ecology of cryptic coral reef communities. IV. Community development and life histories of encrusting cheilostome Bryozoa. J. exp. mar. Biol. Ecol. 76: 1-24

Wishart, D. (1978). Clustan user manual, Program library unit. Univ. of Edinburgh, U.K.

Young, C. M., Chia, F. S. (1981). Laboratory evidence for the delay of larval settlement in response to a dominant competitor. Int. J. invertebr. Reprod. 3: 221-226 